\title{
Zero Tillage Plus Residue Management and K Fertilization Effect on Cotton Yield and K Use Efficiency in Wheat-Cotton System
}

\author{
Niamat Ullah Khan ${ }^{1 *}$, Aftab Ahmad Khan ${ }^{2}$, Sami Ullah ${ }^{3}$, Imran Ullah $^{4}$ and Shitab Khan ${ }^{4}$ \\ 1.Cotton Research Station, PCCC, Dera Ismail Khan \\ 2.Global Change Impact Studies Centre, Islamabad \\ 3.Department of Agronomy, College of Agriculture, BahauddinZakaria University, Layyah \\ 4.Agricultural Research Institute, Dera Ismail Khan
}

\begin{abstract}
Zero tillage straw retained with optimum $\mathrm{K}$ is an important strategy to increase cotton (Gossypium hirsutum L.) yield and $\mathrm{K}$ efficiency in wheat (Triticum aestivum L.)-cotton system. A 2 years field experiment was conducted during 2018, and 2019 to study the impact of [zero tillage straw as such on soil surface $\left(\mathrm{ZT}_{\mathrm{SAS}}\right)$ and zero tillage straw burnt $\left.\left(\mathrm{ZT}_{\mathrm{SB}}\right)\right]$ and five $\mathrm{K}$ rates were $0,20,40,60$ and $80 \mathrm{~kg} \mathrm{ha}^{-1}$ on cotton yield and $\mathrm{K}$ use efficiency. Results indicated that bolls/plant ${ }^{-1}$, weight per boll, seed cotton yields, ginning out turn and $\mathrm{K}$ agronomic efficiency were highest with $60-80 \mathrm{~kg} \mathrm{~K} \mathrm{ha}^{-1}$. Interactions revealed that $\mathrm{ZT}_{\mathrm{SAS}}$ with $60-80 \mathrm{~kg} \mathrm{~K} \mathrm{ha}^{-1}$ had higher bolls/plant, bolls weight, seed cotton yields and ginning out turn compared to $\mathrm{ZT}_{\mathrm{SB}} . \mathrm{K}$ agronomic efficiency indices decreased with increasing $\mathrm{K}$ rate. $\mathrm{ZT}_{\mathrm{SAS}}$ with $20 \mathrm{~kg} \mathrm{~K}^{-1}$ gave greater $\mathrm{K}$ agronomic efficiency than other combinations. $\mathrm{ZT}_{\mathrm{SAS}}$ with $60-80 \mathrm{~kg}$ potassium per hectare may be a sustainable and environmentally safe strategy to enhance cotton yield and soil fertility .
\end{abstract}

Keywords: Zero tillage, residue management, potassium, cotton yield, K agronomic efficiency

DOI: $10.7176 / \mathrm{CPER} / 64-03$

Publication date: January $31^{\text {st }} 2022$

\section{INTRODUCTION}

Zero tillage plus straw retained as such on surface $\left(\mathrm{ZT}_{\mathrm{SAS}}\right)$ is a suitable tillage method that increased soil fertility and cotton production as compared to zero tillage straw burnt, $\mathrm{ZT}_{\mathrm{SB}}$ (Ishaq et al., 200; Hulugalle et al., 2004). Zero tillage (ZT) impacted soil, water and environment. ZT with wheat residues is feasible and economical in wheat, cotton rotation (Wang, 2006). Zero tillage plus residues is the possible alternative to builds up organic matter in the surface of soil, increase moisture absorption capability, improve soil prosperities and increased cotton yield (Boquetet al., 2004). ZT plus residues enhanced SOM and potassium in the soil (Doganet al., 2009). Cotton scientists said that ZT with residue mulch gave higher size of aggregates, stability and total organic carbon in soil aggregates than ZT straw burnt (Mert et al., 2006). Higher accumulation of organic matter in the soil, greater fertilizer use efficiency and optimum moisture accessibility increased cotton yield under zero tillage straw retained (Nyakatawa and Reddy, 2000;Blaise, 2011).

Crop residues retained on soil surface recommended for moisture conservation in cotton sown after wheat (Kumar and Goh, 2000; Pabin et al., 2004). Straw as mulch enhanced K agronomic efficiency and crop yield (Kumar et al., 2000; Endale et al., 2002; Jan et al., 2012). In long term mulched catch crops approach also increased microbial biomass (Goyal et al., 2005; Chan, et al., 2001; Usman et al., 2013; Beri et al., 2003).

Potassium is a major macro fertilizer that needed in large quantity and significantly affect cotton production and K agronomic efficiency (Kumar and Goh 2000; Torbertet al., 2002; Xuet al., 2009; Usman et al., 2014). Cotton crop requires optimum potassium for maximum production. Higher and lower K rates greatly influenced cotton yield and efficiency (Kumar et al., 2000; Singh et al., 2006; Jan et al., 2012; Wang et al., 2007). Potassium deficiency resulted in number of bolls per plant and boll weight that reduced cotton yield. (Sijtsma et al.,(1998), Schwab et al., (2002), Tewolde et al.,(2008), and Reddy et al.,(2012). Potassium uptake could be improved through zero tillage and nutrients availability (Su et al. 2008; Sharma et al. 2002; Beri et al., 2003; Hu, W et al., 2015; Endale et al., 2002; Unay et al., 2005; Singh et al., 2005; Xu, et al., 2009). K use efficiency depends on fertilizer application rate and soil tillage methods (Pettigrew et al., 2001; Nyakatawa et al., 2001; Norsworthy et al., 2010; Potter et al., 2011; Cassman et al., 200; et al., 2001; Minton et al., 1991; Pettigrew et al., 2008). K use in conational cotton sown after is decidedly un-productive (Kienzler, 2010; Dong et al., 2012), having less N recovery efficiency (Reddy et al., (2009) and Reddy et al., (2001). Research findings showed that the zero tillage straw retained with proper nitrogen use has shown to be a possible alternative for sustainable cotton crop production in irrigated wheatcotton systems (Zhang, et al., 2007; Wang, et al., 2012; Yang, et al., 2014). The experiment was carried out with the aim of zero tillage with residues management and $\mathrm{K}$ levels on cotton yield and $\mathrm{K}$ agronomic efficiency in arid environment of Dera Ismail Khan. 


\section{MATERIALS AND METHODS \\ EXPERIMENTAL SITE \\ EXPERIMENTAL SITE}

Field experiments were carried out during 2018 and 2019 at Cotton Research Station, PCCC, Dera Ismail Khan, Pakistan. Dera Ismail Khan district is situated in the south of Khyber Pakhtunkhwa with low rainfall $(<200 \mathrm{~mm} \bullet$ per year), hot and dry are main features of the area. Soil characteristics were shown in Table 2. The weather data were collected from the meteorological centre near the Station, Dera Ismail Khan (Table 1).

\section{TREATMENT AND COTTON MANAGEMENT}

Research trials were carried out in randomized complete block design in split plot having 3 replications. Zero tillage straw as such on soil surface ( $\left.\mathrm{ZT}_{\mathrm{SAS}}\right)$ and zero tillage straw burnt $\left(\mathrm{ZT}_{\mathrm{SB}}\right)$ were assigned to main plots while five $\mathrm{K}$ rates such as $0,20,40,60$ and $80 \mathrm{~kg} \mathrm{ha}^{-1}$ were given to subplots. Wheat was sown in November and was well-fertilized every year so as to reduce the remaining effect of $\mathrm{K}$ rates in the succeeding year. The wheat was harvested on $20^{\text {th }}$ April, leaving all wheat straw in the field. After the harvest of wheat, cotton seed was direct seeded into standing wheat residues with dibbling method in $\mathrm{ZT}_{\mathrm{SAS}}$ plots (making holes with wooden stick) without seed bed preparation during both the study years. While in zero tillage straw burnt $\left(\mathrm{ZT}_{\mathrm{SB}}\right)$ plots, wheat straw vwas burnt and cotton seed was sown by dibbling method. Cotton genotype (CIM-622) was sown on $7^{\text {th }}$ May-2018, $10^{\text {th }}$ May-2019, respectively. $75 \mathrm{~cm}$ row to row and $30 \mathrm{~cm}$ plant to plant was maintained. A net plot size was $10 \mathrm{~m} \times 3 \mathrm{~m}$. NP was given as 150:60 kg ha-1. All P and K were applied during sowing and $\mathrm{N}$ was given in three splits namely a thinning, at flowering and boll formation. All other cultural and protective methods were normally adopted. Seed cotton was picked on November 20, 2018 and November 24, 2019.

\section{DATA COLLECTION}

Data on plant height, boll count per plant, weight per boll in gms, seed cotton yield, kg per hectare, ginning bout turn were recorded using standard procedures.

G.O.T $(\%)=$ weight of lint in sample/weight of seed cotton in sample $\mathrm{x} 100$.

Potassium agronomic efficiency (NAE, kg kg-1),

i.e., the yield ( $\mathrm{kg}$ ha-1) increase for each $\mathrm{kg} \mathrm{K}$ applied, was calculated by formula;

Potassium agronomic efficiency $=\underline{\text { Lint yield } \mathrm{K} \text { - Lint yield } \mathrm{K}_{0}}$

Amount of K applied

\section{STATISTICAL ANALYSIS}

Statistical analyses of the data were performed as per ANOVA techniques (Steel et al., 1980) and significant results were subjected to LSD test for mean comparison using MSTATC software (MSTATC, 1991).

\section{RESULTS}

Plant height (cm)

ANOVA indicated that plant height showed significant response to zero tillage plus residue management, potassium $(\mathrm{K})$ however, it did not respond to ZT plus straw management $\left(\mathrm{ZT}_{\mathrm{SAS}}\right) \times \mathrm{K}$ interaction during b2018-19 (Table 3). $\mathrm{ZT}_{\mathrm{SAS}}$ had the highest plant heightcompared to zero tillage straw burnt $\left(\mathrm{ZT}_{\mathrm{SB}}\right)$. Mean values for potassium revealed that application of $\mathrm{K}$ at the rate of $80 \mathrm{~kg} \mathrm{ha}^{-1}$ produced taller plants amongst all the other potassium rates (Table 4).The results indicate that $\mathrm{ZT}_{\mathrm{SAS}}$ can have productive plant height besides conservation of resources and low cost of cultivation.

Bolls plant ${ }^{-1}$

Boll per plant had significant response to ZT plus straw management and $\mathrm{K}$ whereas interaction was not significant during 2018 and 2019 (Table 3). Means showed that $\mathrm{ZT}_{\mathrm{SAS}}$ had the highest number of bolls (Table 5). K at 60$80 \mathrm{~kg} \mathrm{ha}^{-1}$ produced more boll per plant. Application of $\mathrm{K}$ at $60-80 \mathrm{~kg} \mathrm{ha}^{-1}$ gave higher boll number in $\mathrm{ZT}_{\mathrm{SAS}}$ plots compared to $\mathrm{ZT}_{\mathrm{SB}}$.

\section{Bolls weight-gms}

Bolls weight was affected significantly by ZT plus straw management, potassium, $\mathrm{ZT} \times \mathrm{K}$ interaction during Y1 while in Y2 interaction was not significant (Table- 3). Higher boll weight was recorded with $80 \mathrm{~kg} \mathrm{~K}^{-1}$ as compared to all other combinations (Table 6). Interactions indicated that $\mathrm{ZT}_{\mathrm{SAS}}$ at $80 \mathrm{~kg} \mathrm{~K} \mathrm{ha}^{-1}$ gave heavier boll weight than other treatments.

\section{Seed cotton yield}

Seed cotton yield had significant response to ZT, K and ZT $\times \mathrm{K}$ interactions during 2019 and in $\mathrm{Y} 1$ the interaction was non significant (Table-3). $\mathrm{ZT}_{\mathrm{SAS}}$ had significantly greater yield than $\mathrm{ZT}_{\mathrm{SB}}$ in $\mathrm{Y} 1$ and Y2 (Table 7). Potassium means revealed highest seed cotton yield was obtained from $60-80 \mathrm{~kg} \mathrm{~K} \mathrm{ha}^{-1}$ during two study years. ZT $\times \mathrm{K}$ interactions showed that $\mathrm{ZT}_{\mathrm{SAS}}$ at $80 \mathrm{~kg} \mathrm{~K} \mathrm{ha}^{-1}$ produced highest seed cotton yield. 


\section{Ginning out turn $(\%)$}

Lint percent was affected significantly by ZT, potassium and interactions were not significant (Table- 3 ). $\mathrm{ZT}_{\mathrm{SAS}}$ produced greater ginning out turn \%age than $\mathrm{ZT}_{\mathrm{SB}}$. Maximum GOT was obtained from $80 \mathrm{~kg} \mathrm{~K} \mathrm{ha}^{-1}$ (Table 8). Interactions indicated that optimum lint percentage could be recorded with $80 \mathrm{~kg} \mathrm{~K} \mathrm{ha}^{-1}$ under $\mathrm{ZT}_{\mathrm{SAs}}$.

\section{Potassium Agronomic Efficiency (KAE)}

Potassium agronomic efficiency as the yield $\left(\mathrm{kg} \mathrm{ha}^{-1}\right)$ increase for each $\mathrm{kg} \mathrm{K}$ applied $\left(\mathrm{kg} \mathrm{ha}^{-1}\right)$ is the most important $\mathrm{K}$ use efficiency to producers. KAE was significantly affected by ZT and K and ZT $\times \mathrm{K}$ interactions (Table 3 ). $\mathrm{ZT}_{\mathrm{SAS}}$ resulted in higher KAE than $\mathrm{ZT}_{\mathrm{SB}}$. Potassium application at $20 \mathrm{~kg} \mathrm{ha}^{-1}$ had the greatest agronomic efficiencies, while $80 \mathrm{~kg} \mathrm{~K} \mathrm{ha}^{-1}$ had the lowest KAE (Table 9). Mean values for ZT $\times \mathrm{K}$ interactions revealed that $\mathrm{ZT}_{\mathrm{SAS}}$ in combination with $20 \mathrm{~kg} \mathrm{~K} \mathrm{ha}^{-1}$ gave an optimum NAE.

\section{DISCUSSION}

Zero tillage cotton sown into standing residues of wheat is done on experimental basis in Pakistan. Though, cotton growers take eager attention in ZT cotton establishment after wheat harvest due to lower cost of production and profitable cotton yield (Su et al. 2008; Sharma et al., 2002). Research data revealed that higher bolls per plant observed in ZTsas. Because the plants on the ZTsas plots had more numbers of fruiting sites were greater than those observed in the $\mathrm{ZT}_{\mathrm{SB}}$ (SB-straw burnt). Consequently, ZTsas had greater boll number and weight per boll than $\mathrm{ZT}_{\mathrm{SB}}$. Thus, higher seed cotton was recorded under $\mathrm{ZT}$ sas than under $\mathrm{ZT}_{\mathrm{SB}}$. Enhanced boll retention and weight per boll in ZTsas could be due to other factors such as improved soil K and soil organic matter, differences in nutrient supply and/ or conserved soil moisture. Greater boll numbers and boll weight under ZTsas contributed to yield improvements compared to the $\mathrm{ZT}_{\mathrm{SB}}$ (Pettigrew et al., 2001; Nyakatawa et al., 2001; Norsworthy et al., 2010; Potter et al., 2011; Cassman et al., 200; et al., 2001; Minton et al., 1991; Pettigrew et al., 2008; Kienzler, 2010; Dong et al., 2012). Highest plant height were under ZTsas with optimum K level ( Beri et al., 2003; Hu, W et al., 2015). In long-term study on conservation tillage, significant yield differences were observed in upland cotton (Gormus, \&Yucel , 2002) The study offers great yield variations in cotton genotype under conservation tillage. In addition, improved soil moisture content due straw mulch and better soil physical conditions might have contributed to more number of bolls and yield improvements in ZTsas than ZT $\mathrm{SB}$ (Singh et al., 2005; Xu, et al., 2009). Readet al.,(2006) and Oosterhuis(2010) obtained greater yield due to better soil hydrothermal regime under zero tillage and $\mathrm{K}$ at $80 \mathrm{~kg} \mathrm{ha}^{-1}$. In this research work, Seed cotton yields was significantly encouraged by ZTsas plots compared to plots ZT straw burnt. Seed cotton yield of the residue burnt plots was lowered significantly compared with the straw retained treatments due to the distinctive decrease of bolls, weight per boll and GOT \% age (Kumar et al., 2000; Singh et al., 2006; Jan et al., 2012; Wang et al., 2007; Readet al., 2006; Oosterhuis, 2010). Our results revealed that lower cotton yield in residue burnt treatments, probably due to loss of mainly organic carbon (C) and huge losses of nitrogen (up to 70\%), Phosphorus (26\%) and mainly Potassium $(20 \%)$ and the death of useful soil flora and micro-organisms (Kumar and Goh 2000; Torbertet al., 2002; Xuet al., 2009). While greater seed cotton-yields in residues retained plots maybe due to improved nutrient accessibility in crop residues and right fertilizer management in soil through the adjustment of abundant micro-organisms after returning of wheat residues to the cotton fields (Sijtsma et al., 1998; Schwab et al., 2002; Tewolde et al.,2008; Reddy et al., 2012; Reddy et al., 2009; Reddy et al., 2001). In the first cotton growing year, the micro-organisms might have feed on more nutrients such as potassium and Carbon to meet their own growth need, thus, lesser bolls, weight boll ${ }^{-1}$ and lastly decreased seed cotton yield have reported. However, in the $2^{\text {nd }}$ cotton sowing season, optimum use of soil resources by ZTsas sown cotton and decomposed residues that released fertilizer resulting in higher seed cotton (Zhang, et al., 2007; Wang, et al., 2012; Yang, et al., 2014). Optimum K management in cotton sown in ZTsas with wheat residues retained have increased seed cotton yield due to higher enzymatic activities in boll formation (Pettigrew et al., 2001; Nyakatawa et al., 2001; Norsworthy et al., 2010; Potter et al., 2011). Our results showed $\mathrm{K}$ at $60-80 \mathrm{~kg} \mathrm{ha}^{-1}$ produced number bolls per plant and heavier boll weight as compared other $\mathrm{K}$ treatments (Kaddah, 1997; Kushwaha et al., 2001; Nehra et al., 2005). Enhanced yields in ZTsas with 60-80 kg K ha-1 were probably due to increased $\mathrm{K}$ supply, improved decomposition of wheat straw that enhances biological activity, better cotton root growth because of improved soil structure and enhanced soil moisture content by way of better infiltration rates (Cassman et al., 200; et al., 2001; Minton et al., 1991; Pettigrew et al., 2008; Davis-Carter et al., 1992). Results also showed that ZTsas with wheat residues retention in combination with $80 \mathrm{~kg} \mathrm{~K} \mathrm{ha}^{-1} \mathrm{had}$ comparatively higher Potasssium agronomic efficiency than $\mathrm{ZT}_{\mathrm{SB}}$. This result was probably due to more efficient $\mathrm{K}$ delivery, and lower losses of $\mathrm{K}$ from the system as against $\mathrm{ZT}_{\mathrm{SB}}$ (Prasad and Power 1991; Unger et al., 1997; Schwab et al., 2002; Tursonov. 2009; Pettigrew and Jones 2001; Ishaq et al., 200; Javed et al., 2009; Huang et al., 2001). An optimum yield response could be achieved from combined input of ZT with straw retained and $\mathrm{k}$ fertilizer application at $60 \mathrm{~kg} \mathrm{~K} \mathrm{ha}^{-1}$. This shows that retention of crop residues has led to the increase in the $\mathrm{K}$ contents of soil and microbial activity which is clear indication of an improvement in soil health (Pankhurst et al. 2002; Nie et al. 2007). In the present study, we tried to optimize K management under zero tillage methods in order to improve cotton yield in wheat-cotton system. 


\section{CONCLUSION}

Our data indicate that $\mathrm{ZT}_{\mathrm{SAS}}$ with $60-80 \mathrm{~kg} \mathrm{~K} \mathrm{ha}^{-1}$ had highest plant height, bolls per plant; bolls weight (g), seed cotton yield and ginning out turn as compared to compared to other treatments. K agronomic efficiency indices decreased with increasing $\mathrm{K}$ rate under straw retained than tillage plots with straw burnt. Cotton production with $\mathrm{ZT}_{\text {SAS }}$ may be maintained at minimum cost of cultivation with no environmental hitch. The results of this study indicate that $\mathrm{ZT}_{\mathrm{SAS}}$ with $60 \mathrm{~kg} \mathrm{~K} \mathrm{ha}^{-1}$ can improve cotton yield through conservation of resources.

\section{References}

Angela, Y. Y. K., Fonte, S. J., Kessel, C.V., Six, J. (2009). Transitioning from standard to minimum tillage: Tradeoffs between soil organic matter stabilization, nitrous oxide emissions, and $\mathrm{N}$ availability in irrigated cropping systems. Soil Tillage Research, 104: 256-262.

Avgoulas, C. T., Kotoulas, I. S., Mygdakos, V. E., Economou, G. (2007). Effects of narrow rows and no-tillage on growth parameters, fibre quality and yield components of cotton. Journal Food Agriculture Environment. 5(2): 112-115.

Su, J. L., Ji K. C, Fu C., Lin L, Hai L. Z. (2008). Characteristics of growth and development of winter wheat under zero tillage in North China Plain. Acta Agronomica Sinica, 34, 290-296.

Sharma, R. K., Chhokar, R.S., and Chauhan, D. S. (2002). Zero tillage technology in wheat-cotton system: Retrospect and prospects. Indian Fmg, 54, 12-17.

Chan, K.Y., (2001). An overview of some tillage impacts on earthwormpopulation abundance and diversity implications for functioning in soils. Soil Tillage Research. 57, 179-191.

Cassman, K., Kerby, T., Roberts, B., Bryant, D. \& Higashi, S. (2005). Potassium nutrition effects on lint yield and fiber quality of Acala cotton. Crop Science, 30, 672-677

Minton, E. B., \& Ebelhar, M. W. (1991). Potassium and aldicarb-disulfoton effects on verticillium wilt, yield, and quality of cotton. Crop Science, 31, 209-212.

Hu, W. (2015). Potassium application affects carbohydrate metabolism in the leaf subtending the cotton (Gossypium hirsutum L.) boll and its relationship with boll biomass. Field Crop Research, 179, 120-131

Gormus, O., \& Yucel, C., (2002). Different planting date and potassium fertility effects on cotton yield and fiber properties in the Cukurova region, Turkey. Field Crop Research, 78, 141-149

Read, J. J., Reddy, K. R., \& Jenkins, J. N. (2006). Yield and fiber quality of upland cotton as influenced by nitrogen and potassium nutrition. Eurasian Journal Agronomy, 24, 282-290

Hulugalle, N. R., Nehl, D. B., \& Weaver, T. B. (2004). Soil properties, and cotton growth, yield and fibrequality in three cotton based cropping systems. Soil Tillage Research. 75:131-141.

Ishaq, M., Ibrahim, M., \& Lal, R. (2001). Tillage effect on nutrient uptake by wheat and cotton as influenced by fertilizer rate. Soil Tillage Research, 62:41-43.

Wang, X. (2006). Conservation tillage and nutrient management in dryland farming in China.[Dissertation].Wageningen University.197 p.

Boquet, D. J., Hutchinson, R. L., \& Breitenbeck, G. A. (2004). Long-term tillage, cover crop, and potassium rate effects on cotton. Agronomy Journal, 96:1436-1442.

Mert, M., Aslan, E., Akişcan, Y., \& Çalişkan, M. E. (2006). Response of cotton (Gossypium hirsutum L.) to different tillage systems and intra-row spacing. Soil Tillage Research, 85:221-228.

Nyakatawa, E. Z., Reddy, K. C. (2000). Tillage, cover cropping, and poultry litter effects on cotton:germination and seedling growth. Agronomy Journal, 92:992-999.

Blaise, D. (2011). Tillage and green manure effects on Bt transgenic cotton (Gossypium hirsutum L.) hybrid grown on rainfed Vertisols of central India. Soil Tillage Research, 114:86-96.

Pettigrew, W. T. (2008). Potassium influences on yield and quality production for maize, wheat, soybean and cotton. Physiol Plantarum, 133, 670-681

Davis-Carter, J.G., Baker, S. H. (1992) Potassium Fertilization of Irrigated Cottonon Sandy Loam Soils. In Proceedings of the Beltwide Cotton Conferences, New Orleans, LA, Jan. 10-14,

National Cotton Council of America: Memphis, T. N. (1992) . Reddy, K.R.; Hodges, H.F.; Varco, J.J. Potassium Nutrition of Cotton;Mississippi State University: Mississippi State, MS, 2000; Miss. Agric.Exp. Sta Bull. 1094.

Pankhurst, C. E., McDonald, H. J., Hawke, B. G., Kirkby, C. A. (2002). Effect of tillage and stubble management on chemical and microbiological properties and the development of suppression towards cereal root disease in soil from two sites in NSW, Australia. Soil Biology and Biochemistry, 34, 833-840.

Nie, J., Zhou, J. M., Wang, H. Y., Chen, X. Q., Du, C. W. (2007). Effect of long-term rice straw return on soil glomalin, carbon and nitrogen. Pedosphere, 17, 295-302.

Cassman, K.G., Kerby, T.A., Robert, B. A. (1990) Reassessing PotassiumRequirements of Cotton for Yield and Quality. In Proceedings of theBeltwide Cotton Production Research Conferences, Las Vegas, NV, Jan.9-14, 1990; Brown, J.M.; Richter, D.A., Eds.; National Cotton Council ofAmerica: Memphis, TN,. 
Adeli, A. 1994. Potassium management effects on cotton yield, nutrition and soil test level. Ph.D. dissertation, Mississippi State University, Mississippi State, Mississippi.

Bennett, O. L., Rouse, R. D. and Ashley, D. A. (1965). Yield, fiber quality and potassium content of irrigated cotton plant as affected by rate of potassium. Agronomy Journal, 57: 296-299.

Oosterhuis, D. M. (2010). Foliar fertilization of cotton with potassium. In: Proceedings of a symposium on foliar fertilization of soybeans and cotton, ed. L.S. Murphy, pp. 34-63. PPI/FAR Technical Bulletin 1993-1, Potash and Phosphate Institute/Foundation for Agronomic Research, Norcross, Georgia.

Usman, K., Khan N., Khan, M. U., Saleem, F. Y., Rashid A. (2013a). Impact of tillage and nitrogen on cotton yield and quality in a wheat-cotton system, Pakistan. Archive Agronomy Soil Science 60(4): 519-530.

Read, J.J., Reddy, K. R. Jenkins, J. N. (2006). Yield and fiber quality of upland cotton as influenced by nitrogen and potassium nutrition. European Journal Agronomy, 24: 282-290.

Xu, G. W., Tan, G. L, Wang, Z. Q., Liu, L. J., Yang, J. C. (2009). Effects of wheat residue application and sitespecific potassium management on growth and development in direct-seeding rice. Acta Agronomica Sinica, 35, 685-694.

Kumar, K., Goh, K. M. (2000). Crop residues and management practices: effects on soil quality, soil potassium dynamics, crop yield, and nitrogen recovery. Advances in Agronomy, 68, 197-319.

Beri, V., Sidhu, B. S., Gupta, A. P., Tiwari, R. C., Pareek, R. P., Rupela, O. P., Khera, R., Singh, J., (2003). Organic Resources of a Part of Indogangetic Plain and Other Utilization. Department of Soils,Punjab Agricultural University, Ludhiana.

Endale, D. M., Cabrera, M. L. Steiner, J. L., Radcliffe, D. E., Vencill, W. K., Schomberg, H. H., Lohr, L. (2002). Impact of conservation tillage and nutrient management on soil water and yield of cotton fertilized with poultry litter or ammonium nitrate in the Georgia Piedmont. Soil Tillage Research, 66: 55- 68.

Unay, A., E. Tan, C. Konak, E. Celen. 2005. Influences of winter cover crop residues and tillage on cotton lint yield and quality. Pakistan Journal of Botany, 37(4): 905-911.

Singh, G., Jalota, S.K., Sidhu, B.S. (2005). Soil physical and hydraulicproperties in a rice-wheat cropping system in India: effects of ricestraw management. Soil Use Management, 21, 17-21.

Jan, M. T., Khan, M. J., Farhatullah, M., Arif, M., Afridi, M. Z., Khan, A., Akbar, H. (2012). Integrated management of crop residue and $\mathrm{K}$ fertilizer for wheat production. Pakistan Journal of Botany, 44, 2015 2019.

Wang, X. B., Cai, D. X., Hoogmoed, W.B., O. Oenema, Perdok. U. D. (2007). Developments in conservation tillage in rainfed regions of North China. Soil Tillage. Research, 93: 239-250.

Sharma, R. K., Chhokar, R. S., Chauhan, D. S. (2002). Zero tillage technology in rice-wheat system: retrospect and prospects. Indian Farming, 54, 12-17.

Uri, N. D. (2000). Perceptions on the use of no-till farming in production agriculture in the United States: an analysis of survey results. Agriculture Ecosystem and Environment, 77: 263-266.

Unay, A., E. Tan, C. Konak, E. Celen. (2005). Influences of winter cover crop residues and tillage on cotton lint yield and quality. Pakistan Journal of Botany, 37(4): 905-911.

Torbert, H. A., Ingram, J. T., Ingram J. R., Ingram, R. (2002). High residue conservation tillage system for cotton production: a farmer's perspective. In: Making Conservation Tillage Conventional: Building a Future on 25 Years of Research. Proceedings of the 25th Annual Southern Conservation Tillage Conference For Sustainable Agriculture, Auburn, AL, 24-26 June 2002. Spl. Report No. 1, Alabama Agric. Expt. Stn., Auburn University, USA, pp. 36-41.

Tewolde, H., Shankle, M.W., Sistani, K. R., Adeli, A., Rowe, D. E. (2008) . No-till and conventional-till cotton response to broiler litter fertilization in an upland soil: Lint yield. Agronomy Journal, 100(3): 502-509.

Steel, R. G. D., Torrie, J. H. (1980). Principles and Procedures of Statistics. New York: McGraw Hill Book Co. Inc. $633 \mathrm{p}$.

Sijtsma, C. H., Campbell, A. J., McLaughlin,N. B., and Carter, M. R. (1998). Comparative tillage costs for crop rotations utilizing minimum tillage on a farm scale. Soil Tillage Research, 49: 223-231.

Schwab, E. B., D.W. Reeves, C. H. Burmester, Raper, R.L. (2002). Conservation tillage systems for cotton in the Tennessee Valley. Soil Science Society American Journal, 66: 569-577.

Reddy, S. Nyakatawa, S., Ermson, Z., Chandra, K. (2012). Nitrogen Uptake Pattern by Cotton in a Long-term Notillage System with Poultry Litter Application. Intentional Journal Agriculture Biology ,14(1): 29-37.

Reddy, S. S., Nyakatawa, E. Z., Reddy, K. C., Raper, R. L., Reeves, D. W., Lemunyon, J. L. (2009). Long-term effects of poultry litter and conservation tillage on crop yields and soil phosphorus in cotton-cotton-corn rotation. Intentional Journal Agriculture Biology, 114(2): 311-319.

Reddy, K. C, E.Z. Nyakatawa and R.K. Malik. 2001. Stratigies to sustain cotton production systems in Southeastern USA. Conservation agriculture, aa Worldwide challenge First World Congress on conservation agriculture, Madrid, Spain, 1-5 October 2001. 2:533-537.

Potter, L. Thomas, Truman, C. Clint, Webster, M. Theodore, Bosch, D. David, Strickland, C. Timothy. 2011. 
Tillage, Cover-Crop Residue Management, and Irrigation Incorporation Impact on Fomesafen Runoff. J. Agric. Food Chemistry. 59(14): 7910-7915.

Pettigrew, W.T., M.A. Jones. 2001. Cotton growth under no-till production in the lower Mississippi River Valley alluvial flood plain. Agron. J. 93:1398-1404.

Nyakatawa, E.Z., K.C. Reddy, J.L. Lemunyon. 2001. Predicting soil erosion in conservation tillage cotton production systems using the revised universal soil loss equation (RUSLE). Soil Till. Res. 57, 213-224.

Norsworthy, K., J. McClelland, M. Griffith, Bangarwa, K. Sanjeev, S. Joshua. 2010. Evaluation of legume cover crops and weed control programs in conservation-tillage enhanced glyphosate-resistant cotton. Weed Tech. 24(3): 269-274.

Kushwaha, C.P., S.K. Tripathi and K.P. Singh. 2001. Soil organic matter and waterstable aggregates under different tillage and residue conditions in a tropical drylandagroecosystem. Applied Soil Eco. 16:229-241.

Kaddah, M. T. 1997. Conservation tillage in the Southwest. Available from "Conservation Tillage: Problems and Potentials" Special Publ. Soil Conservation Soc. of Am., Ankeny, Iowa. pp. 57-62.

Lal, R., 1989. Conservation tillage for sustainable agriculture: tropicversus temperate environments. Adv. Agron. 42, 86-197.

Nehra, P.L., Kumawat, P.D., Nehra, K.C., 2005. Effect of tillage, residue management practices and potassium on growth and yield of cotton wheatcropping system of Northwestern Rajasthan. J. Cotton Res. Dev.20, 71-76.

Prasad, R., Power, J.F., 1991. Crop residue management. Adv. SoilSci. 205-251.

Unger, P.W., Schomber, H.M., Doe, T.H., Jones, O.R., 1997. Tillageand crop residue management practices for sustainable dry landfarming systems. Ann. Arid Zone 36, 209-232.

Wruke, M.A., Arnold, W.E., 1985. The effect of three tillage systemson soil properties and corn and soybean growth. In: Proceedingsof the South Dakota Academy Science, vol. 64. pp. 197-207.

Witt C, Cassman K G, Olk D C. Crop rotation and residuemanagement effects on carbon sequestration, nitrogen cyclingand productivity of irrigated rice systems. Plant Soil, 2000,225: 263-278

Díaz-Zorita, M., D.A. Duarte, J. H. Grove. 2002. A review of no-till systems and soil management for sustainable crop production in the sub humid and semiarid pampas of Argentina. Soil Till Res. 65:1-18.

Hao, X., C. Chang, R.L. Conner and P. Bergen. 2001. Effect of minimum tillage and crop sequence on crop yield and quality under irrigation in Southern Alberta clay loam soil. Soil Till. Res. 59: 45-55.

Hunt, P.G., P.J. Bauer, T.A. Matheny. 1997. Crop production in a wheat-cotton double crop rotation with conservation tillage. J. Prod. Agric. 10:462-465.

Endale, D.M., M.L. Cabrera, J.L. Steiner, D.E. Radcliffe, W.K. Vencill, H.H. Schomberg, L. Lohr. 2002. Impact of conservation tillage and nutrient management on soil water and yield of cotton fertilized with poultry litter or ammonium nitrate in the Georgia Piedmont. Soil Till.Res. 66:55- 68.

Gebhardt, M.R., Daniel, T.C., Schweizer, E.E., Allmaras, R.R., 1985. Conservation tillage. Science 230, 625-630.

Govaerts, B., K.D. Sayre, J. Deckers. 2005. Stable high yields with zero tillage and permanent bed planting. Field Crop Res. 94: 33-42.

Hao, X., C. Chang, R.L. Conner and P. Bergen. 2001. Effect of minimum tillage and crop sequence on crop yield and quality under irrigation in Southern Alberta clay loam soil. Soil Till. Res. 59: 45-55.

Van Ouwerkerk, C., Boone, F.R., 1970. Soil physical aspects of zerotillageexperiments. Neth. J. Agric. Sci. 18, 247-261.

Unger, P.W., 1986. Wheat residue management effects on soil waterstorage and corn production. Soil Sci. Soc. Am. J. 50, 764-770.

Singh, B., Malhi, S.S., 2006. Response of soil physical properties totillage and residue management on two soils in a cool temperateenvironment. Soil Tillage Res. 85, 143-153.

Pagliai, M., La Marca, M., Lucamate, G., 1983.Micromorphometricand micromorphological investigation of a clay loam soil inviticulture under zero and conventional tillage. J. Soil Sci. 34,391-403.

Pabin, J., Lipiec, J., Włodek, S., Biskupski, A., 2004. Effect ofdifferent tillage systems and straw management on some physicalproperties of soil and on the yield of winter rye in monoculture. Int.Agrophys. 17, 175-181.

Haines, P.J., Uren, N.C., 1990.Effects of conservation tillage farmingon soil microbial biomass, organic matter and earthworm population,in north-eastern Victoria. Aust. J. Exp. Agric. 30, 365-371.

Goyal, S., Chandler, K., Mundra, M.C., Kapoor, K.K., 2005. Influenceof inorganic fertilizers and organic amendments on soil organicmatter and soil microbial properties under tropical conditions.Biol. Fertil. Soils 29, 196-200.

Ji, S., Unger, P.W., 2001.Soil water accumulation under differentprecipitation, potential evaporation, and straw mulch conditions. Soil Sci. Soc. Am. J. 65, 442-448.

Buck, C., Langmaack, M., Schrader, S., 2000. Influence of mulch andsoil compaction on earthworm cast properties. Appl. Soil Ecol. 14,223-229.

Boone, F.R., Slager, S., Miedema, R., Eleveld, R., 1976. Someinfluences of zero-tillage on the structure and stability of a finetextured river levee soil. Neth. J. Agric. Sci. 24, 105-119. 
Becher, H.H., 2005. Impact of the long-term straw supply on loessderivedsoil structure. Int. Agrophys. 19, 199202.

Chan, K.Y., 2001. An overview of some tillage impacts on earthwormpopulation abundance and diversity implications for functioningin soils. Soil Tillage Res. 57, 179-191.

ANGELA YYK, FONTE SJ, KESSEL CV, SIX J. 2009. Transitioning from standard to minimum tillage: Tradeoffs between soil organic matter stabilization, nitrous oxide emissions, and $\mathrm{N}$ availability in irrigated cropping systems. Soil Till Res 104: 256-262.

DANIEL JB, ABAYE AO, ALLEY MM, ADCOCK CW, MATLAND JC. 1999. Winter annual cover crops in a Virginia no-till cotton production system. II. Cover crop and tillage effects on soil moisture, cotton yield and cotton quality. J Cotton Sci 3: 84-91.

DENG L, CHEN M, LIU Z, SHEN Q, WANG H, WANG J. 2003. Effects of different ground covers on soil physical properties and crop growth on saline-alkaline soil. Chinese J Soil Sci 34(2): 93-97.

GOVAERTS B, SAYRE KD, DECKERS J. 2005. Stable high yields with zero tillage and permanent bed planting. Field Crop Res 94: 33-42.

SAYRE K, HOBBS P. 2004. The raised-bed system of cultivation for irrigated production conditions. In: Lal R, Hobbs P, Uphoff N, Hansen DO, editors. Sustainable Agriculture and the Rice-Wheat System. Columbia, Ohio, USA: Ohio State University. p. 337-355.

USMAN K, KHAN N, KHAN MU, REHMAN AU, GHULAM S. 2013b. Impact of tillage and herbicides on weed density, yield and quality of cotton in wheat based cropping system. JIA 12(9): 1568-1579.

KIENZLER K. 2010. Improving the potassium use efficiency and crop quality in the Khorezm region, Uzbekistan.[Dissertation].ZEF/Rheinische Friedrich-Wilhelms-Universität Bonn.180 p.

GÜRSOY S, SESSIZ A, MALHI SS. 2010. Short-term effects of tillage and residue management following cotton on grain yield and quality of wheat. Field Crop Res 119: 260-268.

HUANG Q, YIN Z, TIAN C. 2001. Effect of two different straw mulching methods on soil solute salt concentration. Arid Land Geog 24: 52-56.

ISHAQ M, IBRAHIM M, LAL R. 2001. Tillage effect on nutrient uptake by wheat and cotton as influenced by fertilizer rate. Soil Till Res 62: 41-53.

JAVED MI, ADIL SA, HASSAN S, ALI A. 2009. An efficiency analysis of Punjab's cotton-wheat system. The Lahore Journal of Economics 14 (2): 97-124.

PETTIGREW WT, JONES MA. 2001. Cotton growth under no-till production in the lower Mississippi River Valley alluvial flood plain. Agron J 93: 1398-1404.

SCHWAB EB, REEVES DW, BURMESTER CH, RAPER RL. 2002. Conservation tillage systems for cotton in the Tennessee Valley. Soil SciSoc Am J 66: 569-577.

TURSONOV M. 2009. Potential of conservation agriculture for irrigated cotton and winter wheat production in Khorezm, Aral Sea Basin. [Dissertation].ZEF/Rheinische Friedrich-Wilhelms-Universität Bonn.247 p.

Wang, N. et al. Genotypic variations in photosynthetic and physiological adjustment to potassium deficiency in cotton (Gossypiumhirsutum L.). Journal of Photochemistry and Photobiology B: Biology 110, 1-8 (2012).

Zhang, Z. et al. Differential responses of conventional and Bt-transgenic cotton to potassium deficiency.J Plant Nutr 30, 659-670 (2007).

Yang, J. et al. Indicators of cotton (Gossypiumhirsutum L.) cultivar screening for low-potassium tolerance in seedling stage and its relationship with yield and quality.Cotton Sci 26, 283-289 (2014, in Chinese with English abstract, 1002-7807(2014)04-0301-09).

Table 1: Monthly seasonal precipitation, temperature and relative humidity (\%) at Cotton Research Station, Dera Ismail Khan during 2015 and 2016 growing seasons

\begin{tabular}{|c|c|c|c|c|c|c|c|c|c|c|c|c|c|c|c|c|}
\hline \multirow{4}{*}{ Month } & \multicolumn{8}{|c|}{2018} & \multicolumn{8}{|c|}{2019} \\
\hline & \multirow{2}{*}{\multicolumn{3}{|c|}{ Temp $\left({ }^{\circ} \mathrm{C}\right)$}} & \multicolumn{4}{|c|}{ Relative humidity (\%) } & \multirow{3}{*}{ Rainfall (mm) } & \multirow{2}{*}{\multicolumn{3}{|c|}{ Temp $\left({ }^{\circ} \mathrm{C}\right)$}} & \multicolumn{4}{|c|}{ Relative humidity (\%) } & \multirow{3}{*}{ Rainfall (mm) } \\
\hline & & & & \multicolumn{2}{|c|}{$800 \mathrm{hrs}$} & \multicolumn{2}{|c|}{$1400 \mathrm{hrs}$} & & & & & & & 140 & & \\
\hline & Max & Min & Mean & Max & Min & Max & Min & & Max & Min & Mean & Max & Min & Max & Min & \\
\hline April & 41 & 13 & 27 & 92 & 52 & 77 & 23 & 38 & 38 & 6 & 22 & 75 & 36 & 56 & 29 & 12 \\
\hline May & 42 & 19 & 31 & 75 & 39 & 63 & 20 & 50 & 45 & 7 & 26 & 57 & 30 & 36 & 23 & 40 \\
\hline June & 44 & 21 & 33 & 81 & 46 & 58 & 27 & 16.5 & 45 & 12 & 29 & 65 & 34 & 50 & 26 & 25.0 \\
\hline $\begin{array}{l}\text { July } \\
\end{array}$ & 42 & 24 & 33 & 81 & 48 & 68 & 36 & 60 & 45 & 18 & 32 & 73 & 30 & 42 & 23 & 111 \\
\hline August & 40 & 23 & 32 & & & & & 35 & 41 & 20 & 31 & 73 & 42 & 49 & 26 & 43 \\
\hline September & 39 & 20 & 30 & 82 & 65 & 71 & 28 & 20 & 40 & 18 & 29 & 73 & 42 & 41 & 22 & 40.0 \\
\hline October & 34 & 19 & 27 & & & & & 4 & 36 & 18 & 27 & 72 & 52 & 52 & 25 & - \\
\hline November & 30 & 6 & 18 & 90 & 59 & 91 & 65 & - & 31 & 10 & 21 & 81 & 69 & 78 & 53 & - \\
\hline Total rainfall & & & & & & & & 223.5 & & & & & & & & 271.0 \\
\hline
\end{tabular}

Source: Arid Zone Research Council (AZRC), D.I.Khan, Pakistan. 
Table 2 Physico-chemical characteristics of the soils used for the experiments at Cotton Research Station, D.I.Khan.

\begin{tabular}{lll}
\hline Characteristic & Units & Values \\
\hline Sand & $\mathrm{g} \mathrm{kg}^{-1}$ & 140 \\
Silt & - & 330 \\
Clay & - & 410 \\
Texture Classes & - & clay loam \\
PH $(1: 5)$ & & 7.8 \\
Organic matter & $\%$ & 0.81 \\
Total N & $\%$ & 0.03 \\
Available P & $\mathrm{mg} / \mathrm{Kg}$ & 5.6 \\
Available K & $\mathrm{mg} / \mathrm{Kg}$ & 219 \\
EC & $\mathrm{dS} / \mathrm{m}$ & 0.2 \\
$\mathrm{CEC}$ & $\mathrm{m} \cdot \mathrm{e} / 100 \mathrm{~g}$ & 18.2 \\
$\mathrm{CO}{ }_{3}^{2-}$ & - & $\mathrm{Nil}$ \\
$\mathrm{HCO}$ & $\mathrm{mol} / \mathrm{L}$ & 1.7 \\
$\mathrm{CL}$ & - & 3.4 \\
$\mathrm{Ca}+\mathrm{Mg}$ & - & 2.5 \\
$\mathrm{SOu}$ & &
\end{tabular}

Source: A RI, Dera Ismail Khan, Pakistan.

Table 3Analysis of variance (mean squares) of Plant height, bolls plant ${ }^{-1}$, boll weight $(\mathrm{g})$, seed cotton yield (kg $\mathrm{ha}^{-1}$ ), ginning out turn (GOT \%) and potassium agronomic efficiency(KAE; $\mathrm{kg} \mathrm{kg}^{-1}$ ) as influenced by zero tillage plus residue management and potassium rates during 2018 and 2019

\begin{tabular}{|c|c|c|c|c|c|c|c|}
\hline Source & D.F. & $\begin{array}{l}\text { Plant } \\
\text { height }\end{array}$ & $\begin{array}{l}\text { Bolls plant } \\
-\end{array}$ & $\begin{array}{l}\text { Boll } \\
\text { weight }\end{array}$ & $\begin{array}{l}\text { Seed cotton } \\
\text { yield }\end{array}$ & GOT (\%) & $\mathrm{KAE}$ \\
\hline & & & \multicolumn{5}{|l|}{ Y1 (2018) } \\
\hline Replication & 2 & 0.469 & 0.433 & 0.00434 & 123528 & 0.0448 & 0.00057 \\
\hline $\begin{array}{l}\text { Zero tillage } \\
(\mathrm{ZT})\end{array}$ & 1 & $133.141 * *$ & $120.000 * *$ & $0.36300 * *$ & $356648 * *$ & $14.8544 * *$ & $3.96033 * *$ \\
\hline Error a & 2 & 0.474 & 4.900 & 0.00183 & 805 & 0.6356 & 0.00089 \\
\hline Potassium (K) & 4 & $699.975 * *$ & $206.283 * *$ & $0.18313 * *$ & $1070671 * *$ & $8.3749 * *$ & $9.97835^{* *}$ \\
\hline $\mathrm{ZT} \times \mathrm{K}$ & 4 & $1.726^{\mathrm{ns}}$ & $3.917^{\mathrm{ns}}$ & $0.01506 * *$ & $4898^{\mathrm{ns}}$ & $0.6576^{\mathrm{ns}}$ & $0.32633 * *$ \\
\hline Error b & 16 & 1.049 & 4.375 & 0.00033 & 24428 & 1.3883 & 0.00031 \\
\hline & & & \multicolumn{5}{|l|}{ Y2 (2019) } \\
\hline Replication & 2 & 1.233 & 2.396 & 0.00196 & 7920 & 3.1545 & 0.05239 \\
\hline $\begin{array}{l}\text { Zero tillage } \\
(\mathrm{ZT})\end{array}$ & 1 & $168.03 * *$ & $274.216^{* *}$ & $0.05292 *$ & $347979 *$ & $46.3266^{*}$ & $5.35096^{* *}$ \\
\hline Error a & 2 & 0.033 & 1.776 & 0.00229 & 9673 & 1.0195 & 0.03172 \\
\hline Potassium (K) & 4 & $390.42 * *$ & $120.701 * *$ & $0.25895 * *$ & $1592513 * *$ & $24.3931 * *$ & $9.53100 * *$ \\
\hline $\mathrm{ZT} \times \mathrm{K}$ & 4 & $2.12^{\mathrm{ns}}$ & $1.612^{\mathrm{ns}}$ & $0.00435^{\text {ns }}$ & $56806^{*}$ & $0.6125^{\mathrm{ns}}$ & $0.43516^{\mathrm{ns}}$ \\
\hline Error b & 16 & 4.967 & 2.444 & 0.00256 & 12398 & 0.7329 & 0.16029 \\
\hline
\end{tabular}

*, **, Significant at 5\% and $1 \%$ level of probability, respectively. ns, No-significant difference at 5\%. 
Table 4 Impact of zero tillage plus residue management and potassium rate on plant height $(\mathrm{cm})$

\begin{tabular}{|c|c|c|c|c|}
\hline \multirow[t]{2}{*}{ Year } & \multirow[t]{2}{*}{ Potassium rate $\left(\mathrm{kg} \mathrm{ha}^{-1}\right)$} & \multicolumn{2}{|c|}{ Zero tillage plus residue management } & \multirow[t]{2}{*}{ Mean } \\
\hline & & $\mathrm{ZT}_{\mathrm{SB}}$ & $\mathrm{ZT}_{\mathrm{SAS}}$ & \\
\hline \multirow[t]{7}{*}{ Y1 (2018) } & 0 & 89.00 & 95.00 & $92.00 \mathrm{e}$ \\
\hline & 20 & 95.00 & 99.33 & $97.17 \mathrm{~d}$ \\
\hline & 40 & 99.00 & 104.67 & $101.83 \mathrm{c}$ \\
\hline & 60 & 106.00 & 109.00 & $107.50 \mathrm{~b}$ \\
\hline & 80 & 110.00 & 114.67 & $112.33 \mathrm{a}$ \\
\hline & Mean & $99.80 \mathrm{~b}$ & $104.53 \mathrm{a}$ & \\
\hline & $\mathrm{LSD}_{0.05}$ for $\mathrm{ZT}=0.2868$, & & & \\
\hline \multirow[t]{6}{*}{ Y2 (2019) } & 0 & 90.53 & 93.50 & $92.02 \mathrm{e}$ \\
\hline & 20 & 95.70 & 99.67 & $97.68 \mathrm{~d}$ \\
\hline & 40 & 105.23 & 109.60 & $107.42 \mathrm{c}$ \\
\hline & 60 & 110.57 & 114.43 & $112.50 \mathrm{~b}$ \\
\hline & 80 & 115.63 & 121.53 & $118.58 \mathrm{a}$ \\
\hline & Mean & $103.53 \mathrm{~b}$ & $107.75 \mathrm{a}$ & \\
\hline
\end{tabular}

Means of similar alphabets are non significant (LSD 5\%).

$\mathrm{ZT}_{\mathrm{SB}}=$ zero tillage straw burnt

$\mathrm{ZT}_{\mathrm{SAS}}=$ zero tillage straw as such on soil surface

Table5 Impact of zero tillage plus residue management and potassium rate on bolls plant ${ }^{-1}$

\begin{tabular}{|c|c|c|c|c|}
\hline \multirow[t]{2}{*}{ Year } & \multirow[t]{2}{*}{ Potassium rate $\left(\mathrm{kg} \mathrm{ha}^{-1}\right)$} & \multicolumn{2}{|c|}{ Zero tillage plus residue management } & \multirow[t]{2}{*}{ Mean } \\
\hline & & $\mathrm{ZT}_{\mathrm{SB}}$ & $\mathrm{ZT} \mathrm{SAS}_{\text {SAS }}$ & \\
\hline \multirow[t]{7}{*}{ Y1 (2018) } & 0 & 15.80 & 22.03 & $18.92 \mathrm{~d}$ \\
\hline & 20 & 21.10 & 25.83 & $23.47 \mathrm{c}$ \\
\hline & 40 & 22.53 & 28.50 & $25.52 \mathrm{~b}$ \\
\hline & 60 & 25.87 & 31.57 & $28.72 \mathrm{a}$ \\
\hline & 80 & 26.47 & 34.07 & $30.27 \mathrm{a}$ \\
\hline & Mean & $22.35 \mathrm{~b}$ & $28.40 \mathrm{a}$ & \\
\hline & $\mathrm{LSD}_{0.05}$ for $\mathrm{ZT}=2.0940, \mathrm{~K}=1.9133$ & & & \\
\hline \multirow[t]{7}{*}{ Y2 (2019) } & 0 & 19.667 & 22.333 & $21.0 \mathrm{c}$ \\
\hline & 20 & 22.333 & 24.33 & $23.3 \mathrm{bc}$ \\
\hline & 40 & 23.667 & 28.00 & $25.8 \mathrm{~b}$ \\
\hline & 60 & 30.00 & 35.667 & $32.8 \mathrm{a}$ \\
\hline & 80 & 31.667 & 37.00 & $34.3 \mathrm{a}$ \\
\hline & Mean & $25.5 \mathrm{~b}$ & $29.5 \mathrm{a}$ & \\
\hline & $\mathrm{LSD}_{0.05}$ for $\mathrm{ZT}=3.478, \mathrm{~K}=2.560$ & & & \\
\hline
\end{tabular}

Means of similar alphabets are non significant (LSD 5\%).

$\mathrm{ZT}_{\mathrm{SB}}=$ zero tillage straw burnt

$\mathrm{ZT}_{\mathrm{SAS}}=$ zero tillage straw as such on soil surface 
Table 6 Impact of zero tillage plus residue management and potassium rate on boll weight $(\mathrm{g})$

\begin{tabular}{|c|c|c|c|c|}
\hline \multirow[t]{2}{*}{ Year } & \multirow[t]{2}{*}{ Potassium rate $\left(\mathrm{kg} \mathrm{ha}^{-1}\right)$} & \multicolumn{2}{|c|}{ Zero tillage plus residue management } & \multirow[t]{2}{*}{ Mean } \\
\hline & & $\mathrm{ZT}_{\mathrm{SB}}$ & $\mathrm{ZT}_{\mathrm{SAS}}$ & \\
\hline \multirow[t]{7}{*}{ Y1 (2018) } & 0 & 2.27 & 2.38 & $2.32 \mathrm{~d}$ \\
\hline & 20 & 2.60 & 2.67 & $2.63 \mathrm{c}$ \\
\hline & 40 & 2.71 & 2.77 & $2.74 \mathrm{~b}$ \\
\hline & 60 & 2.76 & 2.78 & $2.77 \mathrm{~b}$ \\
\hline & 80 & 2.78 & 2.94 & $2.86 \mathrm{a}$ \\
\hline & Mean & $2.62 \mathrm{~b}$ & $2.71 \mathrm{a}$ & \\
\hline & $\mathrm{LSD}_{0.05}$ for $\mathrm{ZT}=0.0752, \mathrm{~K}=0.0619$ & & & \\
\hline \multirow[t]{6}{*}{ Y2 (2019) } & 0 & $2.41 \mathrm{~h}$ & $2.56 \mathrm{~g}$ & $2.48 \mathrm{e}$ \\
\hline & 20 & $2.65 \mathrm{f}$ & $2.85 \mathrm{c}$ & $2.75 \mathrm{~d}$ \\
\hline & 40 & $2.71 \mathrm{e}$ & $2.91 \mathrm{~b}$ & $2.81 \mathrm{c}$ \\
\hline & 60 & $2.78 \mathrm{c}$ & $2.94 \mathrm{~b}$ & $2.86 \mathrm{~b}$ \\
\hline & 80 & $2.75 \mathrm{~d}$ & $3.14 \mathrm{a}$ & $2.94 \mathrm{a}$ \\
\hline & Mean & $2.66 \mathrm{~b}$ & $2.88 \mathrm{a}$ & \\
\hline
\end{tabular}

Means of similar alphabets are non significant (LSD 5\%).

$\mathrm{ZT}_{\mathrm{SB}}=$ zero tillage straw burnt

$\mathrm{ZT}_{\mathrm{SAS}}=$ zero tillage straw as such on soil surface

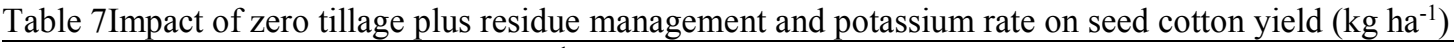

\begin{tabular}{|c|c|c|c|c|}
\hline \multirow[t]{2}{*}{ Year } & \multirow[t]{2}{*}{ Potassium rate $\left(\mathrm{kg} \mathrm{ha}^{-1}\right)$} & \multicolumn{2}{|c|}{ Zero tillage plus residue management } & \multirow[t]{2}{*}{ Mean } \\
\hline & & $\mathrm{ZT}_{\mathrm{SB}}$ & ZT SAS & \\
\hline \multirow[t]{7}{*}{ Y1 (2018) } & 0 & 1145.0 & 1373.0 & $1259.0 \mathrm{~d}$ \\
\hline & 20 & 1437.3 & 1655.3 & $1546.3 \mathrm{c}$ \\
\hline & 40 & 1782.0 & 1964.3 & $1873.2 \mathrm{~b}$ \\
\hline & 60 & 2089.3 & 2245.0 & $2167.2 \mathrm{a}$ \\
\hline & 80 & 2115.0 & 2421.3 & $2268.2 \mathrm{a}$ \\
\hline & Mean & $1713.7 \mathrm{~b}$ & $1931.8 \mathrm{a}$ & \\
\hline & $\mathrm{LSD}_{0.05}$ for $\mathrm{ZT}=44.588$, & & & \\
\hline \multirow[t]{7}{*}{ Y2 (2019) } & 0 & $1053.3 \mathrm{~h}$ & $1579.3 \mathrm{~g}$ & $1316.3 \mathrm{e}$ \\
\hline & 20 & $1791.7 \mathrm{fg}$ & $1932.0 \mathrm{ef}$ & $1861.8 \mathrm{~d}$ \\
\hline & 40 & $2111.3 \mathrm{de}$ & $2160.0 \mathrm{~cd}$ & $2135.7 \mathrm{c}$ \\
\hline & 60 & $2357.0 \mathrm{bc}$ & $2440.0 \mathrm{~b}$ & $2398.5 \mathrm{~b}$ \\
\hline & 80 & $2512.0 \mathrm{~b}$ & $2791.0 \mathrm{a}$ & $2651.5 \mathrm{a}$ \\
\hline & Mean & $1965.1 \mathrm{~b}$ & $2180.5 \mathrm{a}$ & \\
\hline & $\mathrm{LSD}_{0.05}$ for $\mathrm{ZT}=154.52$ & $\mathrm{~T} \times \mathrm{K}=192$ & & \\
\hline
\end{tabular}

Means of similar alphabets are non significant (LSD 5\%).ZT $\mathrm{T}_{\mathrm{SB}}=$ zero tillage straw burnt

$\mathrm{ZT}_{\mathrm{SAS}}=$ zero tillage straw as such on soil surface 
Table 8Impact of zero tillage plus residue management and potassium rate on ginning out turn (\%)

\begin{tabular}{|c|c|c|c|c|}
\hline \multirow[t]{2}{*}{ Year } & \multirow[t]{2}{*}{ Potassium rate $\left(\mathrm{kg} \mathrm{ha}^{-1}\right)$} & \multicolumn{2}{|c|}{ Zero tillage plus residue management } & \multirow[t]{2}{*}{ Mean } \\
\hline & & $\mathrm{ZT}_{\mathrm{SB}}$ & ZT SAS & \\
\hline \multirow[t]{7}{*}{ Y1 (2018) } & 0 & 35.41 & 37.32 & $36.36 \mathrm{c}$ \\
\hline & 20 & 36.20 & 38.37 & $37.28 \mathrm{bc}$ \\
\hline & 40 & 37.32 & 38.73 & $38.02 \mathrm{ab}$ \\
\hline & 60 & 38.18 & 39.19 & $38.68 \mathrm{ab}$ \\
\hline & 80 & 39.12 & 39.66 & $39.39 \mathrm{a}$ \\
\hline & Mean & $37.25 \mathrm{~b}$ & $38.65 \mathrm{a}$ & \\
\hline & $\mathrm{LSD}_{0.05}$ for $\mathrm{ZT}=1.2526$, & & & \\
\hline \multirow[t]{6}{*}{ Y2 (2019) } & 0 & 34.15 & 37.15 & $35.65 \mathrm{~d}$ \\
\hline & 20 & 35.08 & 38.08 & $36.58 \mathrm{~d}$ \\
\hline & 40 & 37.06 & 39.04 & $38.05 \mathrm{c}$ \\
\hline & 60 & 38.45 & 40.08 & $39.26 \mathrm{~b}$ \\
\hline & 80 & 39.26 & 42.08 & $40.67 \mathrm{a}$ \\
\hline & Mean & $36.80 \mathrm{~b}$ & $39.28 \mathrm{a}$ & \\
\hline
\end{tabular}

Means of similar alphabets are non significant (LSD 5\%).

$\mathrm{ZT}_{\mathrm{SB}}=$ zero tillage straw burnt

$\mathrm{ZT}_{\mathrm{SAS}}=$ zero tillage straw as such on soil surface

Table 9Impact of zero tillage plus residue management and potassium rate on $\mathrm{K}$ agronomic efficiency

\begin{tabular}{|c|c|c|c|c|}
\hline \multirow[t]{2}{*}{ Year } & \multirow[t]{2}{*}{ Potassium rate $\left(\mathrm{kg} \mathrm{ha}^{-1}\right)$} & \multicolumn{2}{|c|}{ Zero tillage plus residue management } & \multirow[t]{2}{*}{ Mean } \\
\hline & & $\mathrm{ZT}_{\mathrm{SB}}$ & ZT SAS & \\
\hline \multirow[t]{7}{*}{ Y1 (2018) } & 0 & - & - & - \\
\hline & 20 & $2.64 \mathrm{c}$ & $3.75 \mathrm{a}$ & $3.20 \mathrm{a}$ \\
\hline & 40 & $2.45 \mathrm{~d}$ & $3.52 \mathrm{~b}$ & $2.99 \mathrm{~b}$ \\
\hline & 60 & $1.94 \mathrm{f}$ & $2.47 \mathrm{~d}$ & $2.21 \mathrm{c}$ \\
\hline & 80 & $1.08 \mathrm{~g}$ & $2.00 \mathrm{e}$ & $1.54 \mathrm{~d}$ \\
\hline & Mean & $1.62 \mathrm{~b}$ & $2.35 \mathrm{a}$ & \\
\hline & $\mathrm{LSD}_{0.05}$ for $\mathrm{ZT}=0.0470$ & $\mathrm{ZT} \times \mathrm{K}=0$. & & \\
\hline \multirow[t]{7}{*}{ Y2 (2019) } & 0 & - & - & - \\
\hline & 20 & 2.57 & 3.74 & $3.16 \mathrm{a}$ \\
\hline & 40 & 2.17 & 3.57 & $2.87 \mathrm{a}$ \\
\hline & 60 & 1.96 & 2.66 & $2.31 \mathrm{~b}$ \\
\hline & 80 & 1.11 & 2.1 & $1.59 \mathrm{c}$ \\
\hline & Mean & $1.56 \mathrm{~b}$ & $2.41 \mathrm{a}$ & \\
\hline & $\mathrm{LSD}_{0.05}$ for $\mathrm{ZT}=0.2798$ & & & \\
\hline
\end{tabular}

Means of similar alphabets are non significant (LSD 5\%).

$\mathrm{ZT}_{\mathrm{SB}}=$ zero tillage straw burnt

$\mathrm{ZT}_{\mathrm{SAS}}=$ zero tillage straw as such on soil surface 